\title{
Early Surgery Is Feasible for a Very Large Congenital Infantile Fibrosarcoma Associated With Life Threatening Coagulopathy: A Case Report and Literature Review
}

OPEN ACCESS

Edited by:

Ulf Kessler,

Hirslanden, Switzerland

Reviewed by:

Bilgehan Yalcin

Hacettepe University, Turkey Serhan Küpeli,

Çukurova University, Turkey

${ }^{*}$ Correspondence: Hamidah Alias

midalias@ppukm.ukm.edu.my

Specialty section:

This article was submitted to Pediatric Orthopedics, a section of the journal Frontiers in Pediatrics

Received: 18 September 2019 Accepted: 05 December 2019 Published: 19 December 2019

Citation:

Alias H, Abdul Rashid AH, Lau SCD, Loh C-K, Sapuan J, Ibrahim S, Zin RRM, Chow YP, Kanegane $\mathrm{H}$ and Eguchi M (2019) Early Surgery Is Feasible for a Very Large Congenital Infantile Fibrosarcoma Associated With Life Threatening Coagulopathy: A

Case Report and Literature Review. Front. Pediatr. 7:529 doi: 10.3389/fped.2019.00529

\begin{abstract}
Hamidah Alias ${ }^{1,2 *}$, Abdul Halim Abdul Rashid ${ }^{3}$, Sie Chong Doris Lau ${ }^{1}$, C-Khai Loh ${ }^{1}$, Jamari Sapuan ${ }^{3}$, Sharaf Ibrahim ${ }^{3}$, Reena R. Md Zin ${ }^{4}$, Yock Ping Chow ${ }^{2}$, Hirokazu Kanegane ${ }^{5}$ and Mariko Eguchi ${ }^{6}$

${ }^{1}$ Department of Pediatrics, The National University of Malaysia, Kuala Lumpur, Malaysia, ${ }^{2}$ UKM Medical Molecular Biology Institute, The National University of Malaysia, Kuala Lumpur, Malaysia, ${ }^{3}$ Department of Orthopedic and Traumatology, The National University of Malaysia, Kuala Lumpur, Malaysia, ${ }^{4}$ Department of Pathology, Faculty of Medicine, The National University of Malaysia, Kuala Lumpur, Malaysia, ${ }^{5}$ Department of Pediatrics and Developmental Biology, Graduate School of Medical and Dental Sciences, Tokyo Medical and Dental University, Tokyo, Japan, ${ }^{6}$ Department of Pediatrics, Graduate School of Medicine, Ehime University, Toon, Japan
\end{abstract}

Background: Congenital infantile fibrosarcoma (CIF) is a rare malignant soft tissue tumor that predominantly occurs in children under 1 year of age. CIF is frequently misdiagnosed with other conditions like hemangioma of infancy, infantile fibromatosis, or kaposiform hemangioendothelioma. Disseminated intravascular coagulopathy (DIVC) is rarely reported to be associated with CIF.

Case presentation: We describe an infant who presented with a large mass over the right arm. She was initially treated conservatively as hemangioma but was later confirmed by tissue histopathological examination to have CIF as the mass rapidly increased in size. She developed massive intra-tumoral bleed with DIVC whilst receiving neoadjuvant chemotherapy requiring multiple blood products transfusion. An urgent near-total resection of the tumor was performed in view of life threatening bleeding despite multiple blood transfusions. Post-operatively, she received further adjuvant chemotherapy. Subsequently, she remained in complete remission 32 months off-treatment and has full function of the affected limb.

Conclusions: CIF is an important condition to be considered in infant who has large mass over the extremity. DIVC could be associated with large CIF and when it occurs can be life-threatening. Whenever feasible early surgery should be performed in very young patients with large CIF to prevent mortality from bleeding.

Keywords: congenital infantile fibrosarcoma, coagulopathy, infantile tumor, surgery, chemotherapy

\section{BACKGROUND}

A large upper extremity mass in an infant can be very challenging to diagnose as several conditions could have similar clinical appearance. Differential diagnoses include hemangioma of infancy, lymphatic malformation, rapidly involuting congenital hemangioma, kaposiform hemangioendothelioma, congenital fibrosarcoma, infantile myofibromatosis, 

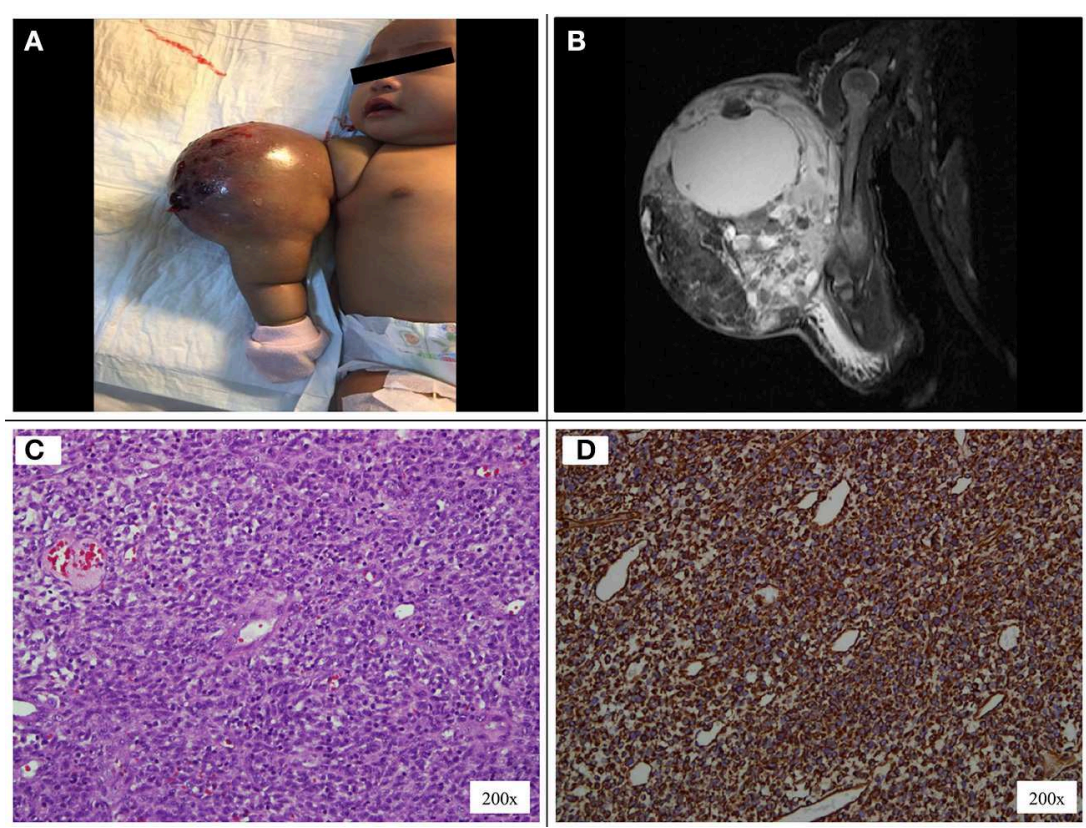

FIGURE 1 | (A) Vascular-appearing mass with bluish discoloration of the overlying skin at the right arm. (B) MRI T1-weighted image shows a large, well-defined, lobulated intramuscular mass at the mid and distal right arm, measuring $5.7 \times 5.3 \times 6.8 \mathrm{~cm}$. (C) The tumor cells display uniform, round, oval to spindle shaped hyperchromatic nuclei and scanty cytoplasm. (D) On immunohistochemical staining the tumor cells are positive to vimentin.

primary myxoid mesenchymal tumor of infancy, and some other rare tumors (1-5). Congenital infantile fibrosarcoma (CIF) is a rare pediatric soft-tissue sarcoma and is typically observed in children $<1$ year of age (6-8). Although it is locally aggressive, metastasis is rare. A recent finding of translocation $t(12 ; 15)(\mathrm{p} 13 ; \mathrm{q} 25)$ between the ETV6 gene and the NTRK3 gene has been specifically associated with $\operatorname{CIF}(9,10)$. ETV6NTRK3 fusion occurs early in the oncogenesis of CIF, thus provides a useful marker for diagnosis. Massive bleeding or disseminated intravascular coagulopathy (DIVC) associated with CIF could be a feature in the very young infant, and requires urgent intervention (11). We report an infant with a large CIF of the right arm who developed DIVC during preoperative chemotherapy. The infant underwent urgent surgery to prevent mortality from the massive bleeding.

\section{CASE PRESENTATION}

A 7-week-old full-term girl presented with a large mass over the right arm. The mass was first noticed at birth to be a 2 $\times 2-\mathrm{cm}$ in size and was treated conservatively as congenital hemangioma. However, at 5 weeks old, the mass had rapidly increased in size. On physical examination, the patient had a firm, non-pulsatile, vascular-appearing mass, $6 \times 5 \times 7$ $\mathrm{cm}$ in size, with an overlying skin of bluish discoloration and a few bleeding spots (Figure 1A). There was no lymph node

Abbreviations: CIF, Congenital infantile fibrosarcoma; DIVC, Disseminated intravascular coagulopathy; MRI, Magnetic resonance imaging; CT, Computerized tomography; MAG3, Mercaptoacetyltriglycine. swelling in the right upper arm, cubital fossa, or axilla. MRI revealed a large, well-defined intramuscular mass at the mid and distal right arm, predominantly iso-intense to muscle on T1-weighted sequence, and heterogeneously hyperintense on T2-weighted sequence (Figure 1B). The MRI findings were interpreted as being consistent with a bleeding intramuscular infantile hemangioma, and she was observed without any treatment. However, the mass continued to grow rapidly, hence a biopsy was performed to ascertain the diagnosis. The histopathological examination showed dense cellular neoplastic spindle cells arranged in short interlacing fascicles with mild pleomorphism, and frequent mitoses (Figure 1C). Some areas with prominent hemangiopericytoma-like vascular pattern were observed. Immunohistochemical stains were negative for desmin, muscle-specific actin, myoD1, CD34, BCL-2, S100, and positive for vimentin (Figure 1D). Based on these findings, a diagnosis of CIF was made. A complete staging which included CT scan of the chest and abdomen, bone scan, and bilateral bone marrow aspirate and trephine was performed and revealed no evidence of metastasis.

The patient was started on VAC chemotherapy, modified at $50 \%$ of the usual dose (vincristine: $0.025 \mathrm{mg} / \mathrm{kg} / \mathrm{dose}$, actinomycin D: $0.025 \mathrm{mg} / \mathrm{kg} /$ dose) without an alkylating agent. Pre-chemotherapy assessment revealed normal cardiac, renal and liver function. Her initial full blood count also showed normal hemoglobin and platelet count. During the 2nd week of chemotherapy, she developed massive intra-tumoral bleed with DIVC; the mass size had increased markedly. A repeat MRI showed increased mass size to $10.3 \times 11.3 \times 12.3-\mathrm{cm}$ with intra-tumoral hemorrhage. The coagulation parameters showed prothrombin time of $18.3 \mathrm{~s}$ with INR ratio of 1.57 , 
activated prothrombin time (APTT) of $61.2 \mathrm{~s}$ with APTT ratio of 1.58, fibrinogen level of $0.6 \mathrm{~g} / \mathrm{l}$, and D-dimer of 19.21 $\mathrm{ug} / \mathrm{ml}$. She required multiple platelet, fresh frozen plasma (FFP), cryoprecipitate and red blood cells transfusions. Despite multiple blood products transfusion the DIVC parameters did not improve significantly and the hemoglobin level dropped to lowest of $5.7 \mathrm{~g} / \mathrm{dL}$ and platelet of $21 \times 10^{9} / \mathrm{L}$. Clinically, continuous blood oozing from few bleeding spots on the tumor surface was observed. At this juncture a multidisciplinary discussion was made to decide on life-saving tumor resection. A high risk informed consent explaining on the risk of right upper limb amputation and mortality from profuse bleeding intraoperatively was obtained from the parents. An urgent angiogram was then performed and embolization of 2 branches of the posterior circumflex right humeral artery was performed before proceeding to tumor excision. Intra-operatively, the tumor measured $16 \times 16-\mathrm{cm}$ and involved the lateral head of triceps and lateral side of biceps. There was bleeding hematoma within the tumor. She required multiple blood products transfusion throughout the surgery; $50 \mathrm{mls} / \mathrm{kg}$ of packed red blood cells transfusion, $30 \mathrm{mls} / \mathrm{kg}$ of FFP transfusion, $15 \mathrm{mls} / \mathrm{kg}$ of platelet and cryoprecipitate transfusions, respectively. The orthopedic surgeons were able to salvage the limb by performing near-total resection of the tumor. The radial nerve which was entrapped within the tumor was preserved. Post-operatively the patient's hemodynamic status was stable and the hemoglobin level had increased to $7.9 \mathrm{mg} / \mathrm{dL}$ and platelet of $243 \times 10^{9} / \mathrm{L}$. The DIVC resolved within $24 \mathrm{~h}$ post-operatively and there was no inotropic support needed. An ETV6(TEL)-NTRK3(TRKC) transcript was detected by reverse transcriptase-polymerase chain reaction, indicating the molecular diagnosis of CIF (Figure 2). Subsequent MRI showed residual tumor in the biceps brachii (anterior lateral) and in the long head of triceps. She completed another 5 cycles of chemotherapy post-operatively. MRI performed at the end of treatment, 24 and 30 months off treatment revealed no residual lesion. Currently she is almost 3 years off treatment and has remained well. She has full function of the right limb.

\section{DISCUSSION}

CIF is a rapidly growing tumor, and in a few weeks or months could become highly vascular. The extremities are

\section{RT-PCR}

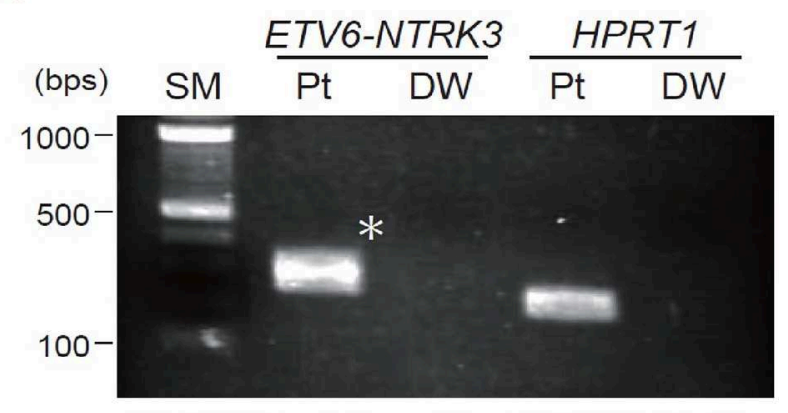

SM : size marker, Pt : patient sample

ETV6-NTRK3 :

TEL-981f + TRKC-1921r

HPRT1 (endogenous control):

HPRT1-305f + HPRT1-489r

*: directly sequenced to confirm the fusion

\section{Direct sequencing}

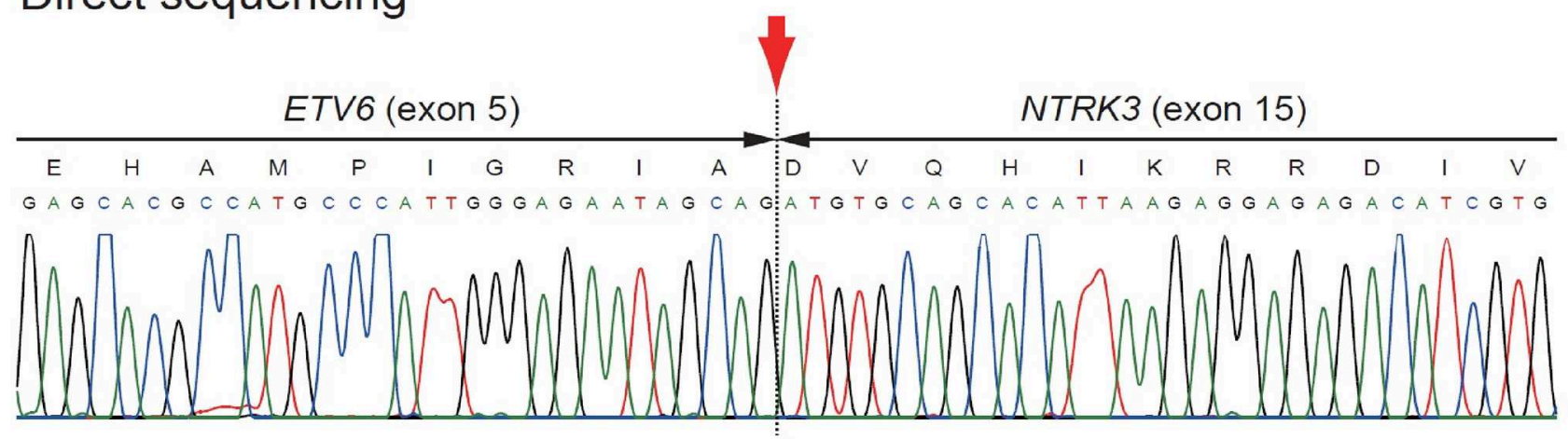

FIGURE 2 | Sequence analysis for ETV6-NTRK3 fusion. 
TABLE 1 | Case report of CIF associated with DIVC.

\begin{tabular}{|c|c|c|c|c|c|c|c|}
\hline References & Gender & Age & Location & Size, $\mathrm{cm}$ & Surgical procedure & Chemotherapy & Outcome \\
\hline \multirow[t]{2}{*}{ Salman et al. (11) } & Male & 2 months & Dorsum right hand & $\begin{array}{l}5.2 \times 4.7 \times \\
1.3\end{array}$ & Subtotal resection & Yes, VAC; 8 cycles & $\begin{array}{l}\text { In remission at } 3 \\
\text { years off treatment }\end{array}$ \\
\hline & Male & 2 months & Left arm & $8.3 \times 5 \times 2.7$ & Gross resection & $\begin{array}{l}\text { Neo-adjuvant, } \\
\text { VAC; } 2 \text { cycles }\end{array}$ & $\begin{array}{l}\text { In remission at } 3 \\
\text { years off treatment }\end{array}$ \\
\hline Duan et al. (8) & Male & 4 days & $\begin{array}{l}\text { Left forearm, } \\
\text { recurrent }\end{array}$ & $8 \times 7 \times 6$ & $\begin{array}{l}\text { Resection; Amputation at } \\
\text { supracondylar level at } \\
\text { recurrence }\end{array}$ & No & In remission \\
\hline Kraneburg et al. (13) & Male & Newborn & Left leg & $\begin{array}{l}11.8 \times 9.3 \times \\
8.5\end{array}$ & $\begin{array}{l}\text { Resection; } \\
\text { through-the-knee } \\
\text { amputation }\end{array}$ & No & $\begin{array}{l}\text { In remission at } 2 \\
\text { years old }\end{array}$ \\
\hline Kerl et al. (2) & Female & Newborn & Left elbow & $\begin{array}{l}10 \text { (in } \\
\text { diameter) }\end{array}$ & Resection & Yes, VAC; 9 cycles & $\begin{array}{l}\text { In remission at } 4 \\
\text { years old }\end{array}$ \\
\hline Dumont et al. (14) & Male & Prenatal & Right leg & $\begin{array}{l}10.7 \times 7.3 \times \\
8.6\end{array}$ & Leg amputation & No & Died at day 8 of life \\
\hline Muzaffar et al. (15) & Female & Prenatal & Left hand & $\begin{array}{l}5.4 \times 7.8 \times \\
4.0\end{array}$ & Resection & $\begin{array}{l}\text { Yes, neo-adjuvant, } \\
\text { VAC; } 2 \text { cycles }\end{array}$ & $\begin{array}{l}\text { In remission at } 22 \\
\text { months old }\end{array}$ \\
\hline Asgari et al. (4) & Female & Newborn & Left palm & $\begin{array}{l}\text { Grapefruit- } \\
\text { sized }\end{array}$ & Resection & $\begin{array}{l}\text { Yes, neo-adjuvant, } \\
\text { VAC }\end{array}$ & $\begin{array}{l}\text { In remission at } 16 \\
\text { months old }\end{array}$ \\
\hline \multirow[t]{2}{*}{ Boon et al. (16) } & Female & Newborn & $\begin{array}{l}\text { Right } \\
\text { cervico-occipital } \\
\text { region }\end{array}$ & $\begin{array}{l}\text { Same size of } \\
\text { her cranium }\end{array}$ & Resection & $\begin{array}{l}\text { Yes, VCR, } \\
\text { adriamycin, } \\
\text { cyclophosphamide }\end{array}$ & $\begin{array}{l}\text { In remission at } 2 \\
\text { years old }\end{array}$ \\
\hline & Male & Newborn & Right scapula & $9 \times 8.5 \times 4.5$ & Resection & N/A & $\begin{array}{l}\text { In remission at } 1 \\
\text { year old }\end{array}$ \\
\hline Walton et al. (17) & Male & Prenatal & Chest wall & $8 \times 8$ & Unresectable & No & Died at $24 \mathrm{~h}$ of life \\
\hline Edwards et al. (18) & Male & $\begin{array}{l}\text { Newborn } \\
\text { (premature) }\end{array}$ & $\begin{array}{l}\text { Left } \\
\text { sacrococcygeal to } \\
\text { left extremity }\end{array}$ & $14.5 \times 11.0$ & Debulking & $\begin{array}{l}\text { Yes, VCR, } \\
\text { dactinomycin }\end{array}$ & $\begin{array}{l}\text { Died at day } 22 \\
\text { of life }\end{array}$ \\
\hline
\end{tabular}

VAC, vincristine, dactinomycin, cyclophosphamide; VCR, vincristine.

affected in most cases of CIF, followed by the head, neck, and trunk. Despite being locally aggressive, CIF is associated with a high long-term survival rate. Surgical excision is the primary treatment modality and, neoadjuvant chemotherapy should be considered in unresectable cases or to reduce morbidity from surgery given the chemosensitive nature of the tumor (12). Bleeding or consumptive coagulopathy is a rare event in CIF and can be life-threatening. Most literature reported the occurrence of massive bleeding or coagulopathy in patients diagnosed within the first 2 months of life, which led to mortality in some patients $(11,13)$. Many of the patients were initially treated as hemangioma of infancy. In our patient, neoadjuvant chemotherapy was given with the aim to prevent limb amputation or mutilating surgery; however, she developed life threatening DIVC while on initial treatment. DIVC complication was previously observed mainly in very young patients with CIF (Table 1). The pathophysiology of consumptive coagulopathy in CIF is not well-understood. However, a similar phenomenon to Kasabach-Merritt syndrome (hemolytic anemia, thrombocytopenia, and secondary consumptive coagulopathy) which occurred in other vascular tumors could be the basis given the high vascularity of CIF. In our case, early surgery of the huge tumor had successfully prevented life threatening complication from DIVC while the patient received neoadjuvant chemotherapy.

\section{CONCLUSION}

Bleeding or DIVC is a rare manifestation of CIF and it could be associated with a large mass in the extremities, trunk, intrathoracic, or intraabdominal. Whenever feasible early surgery should be performed in very young patients with large CIF at risk of life threatening bleeding to prevent mortality.

\section{DATA AVAILABILITY STATEMENT}

All datasets generated for this study are included in the article/supplementary material.

\section{ETHICS STATEMENT}

The National University of Malaysia (UKM) Research Ethics Committee has approved the study. The Research Ethics Committee, The National University of Malaysia operates in accordance to the International Conference of Harmonization Good Clinical Practice Guidelines. Parental written consent has been obtained allowing inclusion of material pertaining to the patient. The patient's parents were informed that no identifying information will be published and this has been acknowledged by them. 


\section{AUTHOR CONTRIBUTIONS}

HA acquired the clinical data and drafted the manuscript. HA, AA, SL, C-KL, JS, and SI were responsible for the clinical management of the patients. RZ and YC were responsible for the pathological diagnosis. ME was responsible for the molecular test and diagnosis. HK and ME were responsible for interpretation of the molecular diagnosis and critical revision

\section{REFERENCES}

1. Enos T, Hosler GA, Uddin N, Mir A. Congenital infantile fibrosarcoma mimicking a cutaneous vascular lesion: a case report and review of the literature. J Cutan Pathol. (2017) 44:193-200. doi: 10.1111/cup.12854

2. Kerl K, Nowacki M, Leuschner I, Masjosthusmann K, Frühwald MC. Infantile fibrosarcoma - an important differential diagnosis of congenital vascular tumors. Pediatr Hematol Oncol. (2012) 29:545-8. doi: 10.3109/08880018.2012.705231

3. Yan AC, Chamlin SL, Liang MG, Hoffman B, Attiyeh EF, Chang B, et al. Congenital infantile fibrosarcoma: a masquerader of ulcerated hemangioma. Pediatr Dermatol. (2006) 23:330-4. doi: 10.1111/j.1525-1470.2006.00257.x

4. Asgari M, Rubin BP, Hornung RL. Neonate with a fibrosarcoma and consumptive coagulopathy. J Am Acad Dermatol. (2004) 50:S23-5. doi: 10.1016/S0190-9622(03)01486-5

5. Hamidah A, Reena M, Halim AR, Ibrahim S, Eguchi M, Zarina AL, et al. Successful treatment of very large congenital infantile fibrosarcoma. Pediatr Int. (2011) 53:768-70. doi: 10.1111/j.1442-200X.2011.03358.x

6. Cecchetto G, Carli M, Alaggio R, Dall'Igna P, Bisogno G, Scarzello G, et al. Fibrosarcoma in pediatric patients: results of the Italian Cooperative Group studies (1979-1995). J Surg Oncol. (2001) 78:225-31. doi: 10.1002/js o.1157

7. Coffin CM, Dehner LP. Soft tissue tumors in first year of life: a report of 190 cases. Pediatr Pathol. (1990) 10:509-26. doi: 10.3109/155138190090 67140

8. Duan S, Zhang X, Wang G, Zhong J, Yang Z, Jiang X, et al. Primary giant congenital infantile fibrosarcoma of the left forearm. Chir Main. (2013) 32:265-7. doi: 10.1016/j.main.2013.06.002

9. Sheng WQ, Hisaoka M, Okamoto S, Tanaka A, Meis-Kindblom JM, Kindblom LG, Ishida $\mathrm{T}$, et al. Congenital-infantile fibrosarcoma. A clinicopathologic study of 10 cases and molecular detection of the ETV6-NTRK3 fusion transcripts using paraffin-embedded tissues. Am J Clin Pathol. (2001) 115:348-55. doi: 10.1309/3H24-E7T7-V37 G-AKKQ

10. Knezevich SR, McFadden DE, Tao W, Lim JF, Sorensen PH. A novel ETV6NTRK3 gene fusion in congenital fibrosarcoma. Nat Genet. (1998) 18:184-7. doi: $10.1038 / \mathrm{ng} 0298-184$ of the manuscript. All authors have read and approved the final manuscript.

\section{ACKNOWLEDGMENTS}

The authors would like to thank the Graduate School of Medicine, Ehime University, Toon, Japan for their support on the molecular diagnosis.

11. Salman M, Khoury NJ, Khalifeh I, Abbas HA, Majdalani M, Abboud M, et al. Congenital infantile fibrosarcoma: association with bleeding diathesis. Am J Case Rep. (2013) 14:481-5. doi: 10.12659/AJCR.889489

12. Akyüz C, Küpeli S, Varan A, Gedikoglu G, Yalçin B, Kutluk T, et al. Infantile fibrosarcoma: retrospective analysis of eleven patients. Tumori. (2011) 97:166-9. doi: 10.1700/667.7778

13. Kraneburg UM, Rinsky LA, Chisholm KM, Khosla RK. Emergency surgical treatment of an ulcerative and hemorrhagic congenital/infantile fibrosarcoma of the lower leg: case report and literature review. J Pediatr Orthop B. (2013) 22:228-32. doi: 10.1097/BPB.0b013e3283536908

14. Dumont C, Monforte M, Flandrin A, Couture A, Tichit R, Boulot P. Prenatal management of congenital infantile fibrosarcoma: unexpected outcome. Ultrasound Obstet Gynecol. (2011) 37:733-5. doi: 10.1002/uog.8878

15. Muzaffar AR, Friedrich JB, Lu KK, Hanel DP. Infantile fibrosarcoma of the hand associated with coagulopathy. Plast Reconstr Surg. (2006) 117:81e-6e. doi: 10.1097/01.prs.0000206314.29607.2b

16. Boon LM, Fishman SJ, Lund DP, Mulliken JB. Congenital fibrosarcoma masquerading as congenital hemangioma: report of two cases. J Pediatr Surg. (1995) 30:1378-81. doi: 10.1016/0022-3468(95)90514-6

17. Walton JM, Rubin SZ, Soucy P, Benzie R, Ash K, Nimrod C. Fetal tumors associated with hydrops: the role of the pediatric surgeon. J Pediatr Surg. (1993) 28:1151-3. doi: 10.1016/0022-3468(93)90152-B

18. Edwards TM, Duran MS, Meeker TM. Congenital infantile fibrosarcoma in the premature infant. Adv Neonatal Care. (2017) 17:440-50. doi: 10.1097/ANC.0000000000000440

Conflict of Interest: The authors declare that the research was conducted in the absence of any commercial or financial relationships that could be construed as a potential conflict of interest.

Copyright (C) 2019 Alias, Abdul Rashid, Lau, Loh, Sapuan, Ibrahim, Zin, Chow, Kanegane and Eguchi. This is an open-access article distributed under the terms of the Creative Commons Attribution License (CC BY). The use, distribution or reproduction in other forums is permitted, provided the original author $(s)$ and the copyright owner(s) are credited and that the original publication in this journal is cited, in accordance with accepted academic practice. No use, distribution or reproduction is permitted which does not comply with these terms. 